\title{
Freeing the Modern Slaves, One Click at a Time: Theorising human trafficking, modern slavery, and technology
}

\author{
Sanja Milivojevic, Heather Moore, and Marie Segrave
}

\section{Abstract}

This paper analyses relations between human trafficking, modern slavery, and information communication technology. It looks at the history of the technologytrafficking nexus and flags some key advances in the counter-trafficking discourse in the last two decades. It provides an overview of how technology has been framed as both a part of the problem and part of the solution in the trafficking/slavery context and emphasises the impact of such developments on a range of actors, in particular, potential victims, NGOs, and the nation state. We suggest that the technology-slavery/trafficking connections, while often elusive, act as potent narrative and policy setters that can advance existing challenges and create new points of tension in the counter-trafficking context. We critically analyse these points of tension and destabilise some of their underpinning assumptions. In the conclusion, we highlight the need for rigorous empirical evidence, arguing that a more robust scholarly engagement with the role of technology in enabling and disrupting exploitation is essential. We also point to the importance of ensuring that technology is not a distraction from addressing the root causes of exploitation and abuse.

Keywords: technology, e-trafficking, impact, evidence-based knowledge

Please cite this article as: S Milivojevic, H Moore, and M Segrave, 'Freeing the Modern Slaves, One Click at a Time: Theorising human trafficking, modern slavery, and technology', Anti-Trafficking Review, issue 14, 2020, pp. 16-32, https:// doi.org/10.14197/atr.201220142

This is an open-access article distributed under the terms of the Creative Commons Attribution License (CC-BY). Under the CC-BY license, the public is free to share, adapt, and make commercial use of the work. Users must always give proper attribution to the authors and the Anti-Trafficking Review. 


\section{The Issue}

Digital frontier technologies, also referred to as innovative and emerging technologies, have radically transformed contemporary societies, economies and the environment. ${ }^{1}$ Importantly, as Castells noted almost two decades ago, for the first time in history the entire planet is capitalist, ${ }^{2}$ and technology is both an essential source of progress and development, as well as profit. In this übercapitalist world, the Information Communication Technologies (ICTs) have been identified as 'roots of new productivity sources' ${ }^{3}$ — critical drivers for the greater good, but also factors that increase the risk of crime and victimisation of women and young people in particular. ${ }^{4}$

The emergence of populist narratives and broad, unsubstantiated claims about the role of the Internet was first chronicled in relation to trafficking for the purpose of sexual exploitation. ${ }^{5}$ The prominent American abolitionist Donna Hughes warned two decades ago that the sexual exploitation of women and children is so widespread that it should be defined as a global human rights crisis and that this crisis is further escalated and promoted by the use of new technologies. ${ }^{6}$ The assertion that the Internet has changed the nature of trafficking by enabling traffickers to reach and exercise control over victims has been consistent across academia and policy domains over the past decade.

In the absence of evidence of a causal relationship between trafficking and ICTs, we have seen the framing of technology as a platform that increases 'risk' for (mostly sexual) exploitation of (mostly women) victims. The fusion of trafficking

$1 \quad$ United Nations, World Economic and Social Survey 2018: Frontier technologies for sustainable development, Department of Economic and Social Affairs, New York, 2018.

2 M Castells, Information Technology, Globalization and Social Development, United Nations Research Institute for Social Development Discussion Paper 114, Geneva, 1999.

3 Ibid., p. 2.

4 Some of these issues are sexting, revenge pornography or image-based sexual abuse, stalking, family violence, and the like.

5 D Hughes, Pimps and Predators at the Internet: Globalizing the sexual exploitation of women and children, University of Rhode Island, 1999.

6 D Hughes, 'The Use of New Communications and Information Technologies for Sexual Exploitation of Women and Children', Hastings Women's Law Journal, vol. 13, no. 1, 2002, pp. 129-148. 
with sex work ${ }^{7}$ has resulted in online monitoring that cites the number of online advertisements for female escort services as evidence for Internet-facilitated or Internet-enabled cases of human trafficking. ${ }^{8}$ Similar efforts have not been channelled into identifying false advertising in the Global South of legal job opportunities in the Global North in horticulture or other industries. Indeed, instead of identifying victims, what we see is a concerted effort to look for unlawful or irregular migrant workers and deport them with no questions asked about labour conditions. ${ }^{9}$ Yet, in the absence of credible evidence, authors often simply reiterate the claim that the relationship between sex trafficking and technology, however uncertain, is likely:

Although there is limited information on the use of new information technologies for sexual exploitation purposes by traffickers, there is no reason to doubt that they are using the latest technologies for trafficking purposes too. ${ }^{10}$

It is not unheard of that a young girl dreaming about being a supermodel would be attracted by a false advertisement online ... Via the Internet, after choosing the right venue to place bait (i.e., false advertisement) human traffickers can practically wait for preys to come to them as opposed to physically hunting them down. The Internet certainly widens the net for human traffickers. ${ }^{11}$

7 M Farley, K Franzblau, and M A Kennedy, 'Online Prostitution and Trafficking', Albany Law Review, vol. 77, issue 3, 2013, pp. 1039-1094. See also Musto's critique of the development of the trafficking/sex work conflation in J Musto, Control and Protect: Collaboration, carceral protection, and domestic sex trafficking in the United States, University of California Press, Oakland, 2016.

8 M Latonero et al., 'Human Trafficking Online: The role of social networking sites and online classifieds', University of Southern Carolina, 2011, retrieved 25 March 2019, https://technologyandtrafficking.usc.edu/files/2011/09/HumanTrafficking_FINAL. pdf. See also: S Milivojevic and M Segrave, 'Gendered Exploitation in the Digital Border Crossing? An analysis of the human trafficking and information technology nexus', in M Segrave and L Vitis (eds.), Gender, Technology and Violence, Routledge, Abingdon Oxon, 2017, pp. 28-44.

9 M Segrave, S Milivojevic, and S Pickering, Sex Trafficking and Modern Slavery: The absence of evidence, Routledge, London and New York, 2018.

10 S Sarkar, 'Use of Technology in Human Trafficking Networks and Sexual Exploitation: A cross-sectional multi-country study', Transnational Social Review, vol. 5, no. 1, 2015, pp. 55-68 (p. 59; our emphasis), https://doi.org/10.1080/21931674.2014.991184.

11 S Yu, 'Human Trafficking and the Internet', in M Palmiotto (ed), Combating Human Trafficking: A multidisciplinary approach, CRC Press, Boca Raton, 2015, pp. 61-74 (p. 66; our emphasis). 
Claims that the Internet and smartphones have contributed to the rise of trafficking ${ }^{12}$ and that the pseudo-anonymity and sheer volume of data makes the Internet 'a new playground' for traffickers ${ }^{13}$ have been since injected into national and international counter-trafficking frameworks. ${ }^{14}$ As Latonero et al. ${ }^{15}$ suggest, the rise of mobile technology is likely to fundamentally transform the practice of trafficking as traffickers take advantage of technology to reach broader audiences and bypass geographical distances. Similarly, as social media platforms such as Facebook, Twitter, Instagram, Snapchat, and others gained traction, so were the assumed links between social media and trafficking. The role of social media in recruiting victims has been increasingly explored, ${ }^{16}$ with Facebook being frequently identified by counter-trafficking actors as a critical forum for traffickers to lure susceptible and vulnerable victims into the sex trade. ${ }^{17}$

This narrative has arguably proliferated with a recent amalgamation of human trafficking within the broader, legally undefined concept of modern slavery. ${ }^{18}$ In a 2015 UK Centre for Social Justice report, it was suggested that:

[w] hen slavery was prevalent over two hundred years ago, there was no Internet. Nor were many slave traders able to purchase low-cost international travel. So slavery as we know it today is modern. It thrives on modern technology and modern forms of travel. ${ }^{19}$

12 A Sykiotou, Trafficking in Human Beings: Internet recruitment, Council of Europe, 2007, p. 22. See also: Sarkar, 2015.

13 Yu, 2015, p. 62.

14 For a detailed development of the international policy, see Milivojevic and Segrave, 2017.

15 Latonero et al., p. iv.

16 D Barney, 'Trafficking Technology: A look at different approaches to ending technology-facilitated human trafficking', Pepperdine Law Review, vol. 45, issue 4, 2018, pp. 747-784.

17 K Guilbert, 'Chasing Shadows: Can technology save the slaves it snared?', Reuters, 21 June 2018, https://www.reuters.com/article/us-technology-trafficking-fight-insight/ chasing-shadows-can-technology-save-the-slaves-it-snared-idUSKBN1JH005.

18 M Segrave, N Piper, and R Napier-Moore, 'What's in a Name? Distinguishing forced labour, trafficking and slavery', Anti-Trafficking Review, issue 5, 2015, pp. 1-9, https:// doi.org/10.14197/atr.20121551.

19 F Cunningham, 'A Modern Response to Modern Slavery', The Centre for Social Justice, 2015, retrieved 25 March 2019, https://www.europol.europa.eu/publicationsdocuments/modern-response-to-modern-slavery (p. 10; our emphasis). 
In the production of these discourses, and the responses they give rise to, technology is constructed as enabling exploitation and violence. This narrative lends itself to a logic of policy response, whereby international agencies and governments react to the 'threats' of technology. ${ }^{20}$ The notion that technology is fuelling modern slavery ${ }^{21}$ is readily embraced. However, technology has simultaneously come to the fore as a formidable tool to combat both trafficking and slavery. What is achieved in this instance, though, is the whitewashing of this complexity, and the silencing of the importance of safe and fair migration and labour opportunities.

In this review paper that draws on anti-trafficking scholarship and our own contributions to the field, we seek to destabilise these assumptions by illuminating the logic that underpins them. In so doing, we point to a major concern of antitrafficking efforts: that shifts in focus (regarding forms of trafficking or the breadth of exploitation) and shifts in processes or tools to identify and address trafficking ensure that the underlying inequalities of access to safe mobility and safe and fair working conditions continue to remain unaddressed.

We first focus on the claims that technology assists traffickers in recruiting victims. Following that is an analysis of technology as a crime prevention tool and an emerging counter-trafficking platform. Next, we look at the impact such developments have on a range of actors: potential victims, businesses, NGOs, counter-trafficking/slavery advocates, and the nation-state. We contextualise the 'trafficking-technology nexus' ${ }^{22}$ having in mind a merger of human trafficking with the concept of modern slavery that has recently consumed the trafficking debate. Our main argument is that the technology-trafficking/slavery connections are often elusive and yet act as a potent narrative that is as challenging to destabilise as the early efforts to protect women via border control. ${ }^{23}$ In the final section of the paper, we call for a different paradigm, a much-needed re-thinking of the debate on the role technology plays in both enabling and countering trafficking/ slavery.

20 Milivojevic and Segrave, p. 30.

21 Guilbert.

22 J Musto and d boyd, 'The Trafficking-Technology Nexus', Social Politics, vol. 21, no. 3, 2014, pp. 461-483, https://doi.org/10.1093/sp/jxu018.

23 Segrave, Milivojevic, and Pickering. 


\section{The Solution}

The notion that technology can offer new tools in combating crime has been explored at length in academia, policy, and public discourse. Claims that 'old fashioned police and detective work is no longer sufficient to fight criminals who are using smartphones and bitcoins ${ }^{24}$ quickly became mainstream. Thus, it comes as no surprise that technology has been identified as a potent counter-trafficking tool. This narrative has particularly gained traction in the United States ${ }^{25}$ and United Kingdom. ${ }^{26}$ The Internet and social media have been pointed out as platforms for possible detection of trafficking and identification and rescue of victims. ${ }^{27} \mathrm{NGOs,} \mathrm{anti-trafficking} \mathrm{organisations,} \mathrm{and} \mathrm{governments} \mathrm{have} \mathrm{been}$ increasingly using social media to warn potential victims-mostly would-be migrants - of the dangers of trafficking and exploitation that can happen if they embark on their mobility projects. ${ }^{28}$ Finally, technology-mediated surveillance has been increasingly used to 'protect' prospective victims and 'rescue' those identified as victims of trafficking. ${ }^{29}$

This narrative has bourgeoned with the expansionist purview of modern slavery which attempts to be a 'catch-all' term for a range of exploitative practices. ${ }^{30}$ The promise of technology as a mechanism to identify and free 'modern slaves' is appealing. Proposals for drones to be used to combat slavery in agriculture and

24 C Maza, 'How Technology is Turning the Tables on Human Traffickers', Mic, 25 December 2013, https://mic.com/articles/77303/how-technology-is-turning-the-tables-on-human-traffickers\#.v7nqGfPNc.

25 See: Musto, 2016.

26 S George, 'BT, Microsoft and Nokia Team Up to Combat Human Trafficking in Supply Chains', Edie, 3 July 2018, https://www.edie.net/news/7/BT--Microsoft-andNokia-team-up-to-combat-human-trafficking-in-supply-chains.

27 Latonero et al.; US Department of State, Trafficking in Persons Report, USDS, Washington, 2011.

28 S Milivojevic, 'The State, Virtual Borders and E-trafficking: Between fact and fiction', in J McCulloch and S Pickering (eds), Borders and Crime. Transnational crime, crime control and security, Palgrave Macmillan, London, 2012; R Gong, 'Indignation, Inspiration, and Interaction on the Internet: Emotion work online in the anti-human trafficking movement', Journal of Technology in Human Services, vol. 33, no. 1, 2015, pp. 87-103, https://doi.org/10.1080/15228835.2014.998988; S Voronova and A Radjenovic, The Gender Dimension of Human Trafficking, European Parliamentary Research Service, 2016, http://www.europarl.europa.eu/RegData/etudes/BRIE/ 2016/577950/EPRS_BRI(2016)577950_EN.pdf.

29 Musto, 2016; see also: Milivojevic and Segrave.

30 J Chuang, 'Exploitation Creep and the Unmaking of Human Trafficking Law', The American Journal of International Law, vol. 108, no. 4, 2014, pp. 609-649, https:// doi.org/10.5305/amerjintelaw.108.4.0609. 
fishing industry are mounting. ${ }^{31}$ It is said that 'drones can be used to hover above a farm, tracking every person's movement ${ }^{32}$ and that they will give a much-needed transparency to a range of business practices where slaves might be found. For example, the project 'Slavery from Space' provides an opportunity to website visitors to help researchers identify potential brick kilns and other suspicious sites for labour exploitation. ${ }^{33}$ The rhetoric of the benevolent victim-rescue has mass appeal..$^{34}$ Yet, such appeal drowns out considered and empirically-based criticism, ${ }^{35}$ and perpetuates the denial and silencing of those who experience exploitation. We return to this important point later in the article.

Alongside the latest version of raid and rescue, we have also seen the rise in facial recognition flagged as a technology that can assist in the identification of victims of trafficking and slavery. ${ }^{36}$ Concerns about the limits and consequences of such technology are silenced by the overwhelmingly moral imperative to 'protect and rescue'. The power of this moralising discourse is such that it is untroubled by the absence of evidence to support this position (or indeed, the mounting evidence that casts doubt on the accuracy of this position). As we demonstrate in the following section, our decades of research with men and women who have been trafficked, exploited and largely ignored has consistently highlighted that recognition is rarely in the interests of those who have experienced exploitation. ${ }^{37}$

Technology, it is argued, can also make all citizens rescuers, with apps for reporting

31 A Brasilero, 'Brazil will use drones to fight slave labour in rural areas', Reuters, 28 July 2015, https://www.reuters.com/article/us-brazil-slavery-drones/brazil-will-usedrones-to-fight-slave-labor-in-rural-areas-idUSKCN0Q226F20150728; C Wilkens, 'Using Drones to Fight Slavery in the Fields: An examination of the practicality and constitutionality of applying $21^{\text {st }}$ century technology to a $21^{\text {st }}$ century problem', Hastings Environmental Law Journal, vol. 24, no. 1, 2018, pp. 157-178; The Global Slavery Index - Fishing, 2018, retrieved 29 March 2019, https://www. globalslaveryindex.org/2018/findings/importing-risk/fishing.

32 Wilkens, p. 164.

33 Slavery from Space, Research, 2019, https://www.zooniverse.org/projects/ezzjcw/ rights-lab-slavery-from-space/about/research. Kevin Bales supervised this project.

34 J O'Connell Davidson, Modern Slavery: The margins of freedom, Palgrave Macmillan, Basingstoke, 2015; see also Segrave, Milivojevic, and Pickering.

35 P Agarwal, 'Can we Really Spot Slavery from Space?', Open Democracy, 3 June 2019, https://www.opendemocracy.net/en/beyond-trafficking-and-slavery/can-we-reallyspot-slavery-space.

36 L Lacy, 'This Startup is Using Facial Recognition to Fight Human Trafficking', Adweek, 31 May 2018, https://www.adweek.com/digital/this-startup-is-using-facial-recognition-to-fight-human-trafficking.

37 Segrave, Milivojevic, and Pickering. 
the incidents of potential cases of slavery recently launched in the UK. ${ }^{38}$ Experts and government agencies have welcomed these avenues for citizen-reporting of slavery: 'The public have always had a key role to play in being the eyes and ears for law enforcement in the UK and creating another mechanism for them to do this through the creation of an app makes a lot of sense. ${ }^{39}$ Such examples of behavioural modification, led by technological innovations, suggest that slavery is a micro problem that should be fought on a micro-level — through mobile phone apps of individual consumers' behaviour, businesses' regulation of supply chains in the Global South, and by individual efforts of morally conscious everyday people of the Global North (and to some extent the Global South). Moreover, such an approach suggests that consumer-based tech-capitalism of neoliberal provenance is the source we need to tap into in our quest to end modern slavery. Within this 'we rally together' movement ${ }^{40}$ that has united feminists, religious and business leaders, politicians, and celebrities, the complex reality of contemporary exploitative practices is simplified and streamlined, with clearly identifiable perpetrators, victims, 'rescuers' and the rest of us that can do 'our bit' to combat trafficking/slavery, via technology.

\section{Rhetoric over Evidence: Key impacts}

Many critics have pointed out that the risk of technology-facilitated trafficking or cyber-slavery has been exaggerated in the counter-trafficking/slavery discourse. ${ }^{41}$ Mendel and Sharapov note that 'pseudo-research' in this area abounds. ${ }^{42}$ Much like research on its terrestrial counterpart, the research related to e-trafficking often violates the standard canons of the social science inquiry. ${ }^{43}$ As Gozdziak points out, peer-reviewed journals have frequently published non-empirical research on trafficking, making the knowledge base on the topic somewhat

38 Unseen, 'Unseen launches app to report modern slavery', 2018, https://www.unseenuk. org/news/55.

39 Roger Bannister, interim chief executive of the Gangmasters and Labour Abuse Authority, cited in Unseen, 2018.

40 O'Connell Davidson.

41 Musto and boyd; see also: J Mendel and K Sharapov, 'Human Trafficking and Online Networks: Policy, analysis, and ignorance', Antipode, vol. 48, no. 3, 2016, pp. 665-684, https://doi.org/10.1111/anti.12213.

42 Mendel and Sharapov, p. 669.

43 R Weitzer, 'Sex Trafficking and the Sex Industry: The need for evidence-based theory and legislation', Journal of Criminal Law and Criminology, vol. 101, no. 4, 2012, pp. 1337-1370, p. 1339. 
skewed. ${ }^{44}$ This 'construction of ignorance' ${ }^{35}$ has resulted in a field in which knowledge is often based on anecdotal case studies and speculations. ${ }^{46}$ Importantly, as we have argued elsewhere, ${ }^{47}$ such accounts have been very effective in informing policy and have successfully infiltrated both the media and public spaces. Dismantling the spurious logic, founded on dominant, simplistic narratives of victimisation, remains as challenging in this context as it did at the turn of the century when the focus was on 'sex slaves' who needed rescuing and liberating from servitude and to be returned home to heal.

Technology in counter-trafficking has been used to scrutinise and often dismiss (mostly women's) entrepreneurial mobility projects. Surveillance of potential victims and offenders, state interventions in the digital sphere, and unconditional cooperation with law enforcement in investigating these crimes are perceived as necessary measures to 'protect' people (in particular, women) from becoming victims. ${ }^{48}$ Global surveillance, thus, is needed to further or enable individual security and freedom. ${ }^{49}$ Yet, in the absence of evidence, there is a gendered and moralising argument that advocates for the rescue of 'innocent victims' at all costs, including their own agency. Indeed, as Ham et al. have pointed out, technology is also utilised to scrutinise women's behaviour and to identify those who are suspicious at the point of border entry-'sexy' clothes and underwear and questionable phone messages are grounds to refuse entry into Australia. ${ }^{50} \mathrm{Within}$ the broader context, what these debates enable is a re-emergence of various trafficking conundrums, not least of which is the privileging of the ideal victim. In what follows we explore the re-emergence of these critical points of tension, as identified in our previous research on the topic.

44 E Gozdziak, 'Data Matters: Issues and challenges for research on trafficking', in M Dragiewicz (ed.), Global Human Trafficking, Taylor and Francis, London, 2014, pp. 23-38.

45 Mendel and Sharapov, p. 668.

46 See: Hughes, 2002; E Kunze, 'Sex Trafficking via the Internet: How international agreements address the problem and fail to go far enough', The Journal of High Technology Law, vol. 10, no. 2, 2010, pp. 241-289; D Hughes, 'Trafficking in Human Beings in the European Union: Gender, sexual exploitation, and digital communication Technologies', Sage Open, October-December, 2014, pp. 1-8, https:// doi.org/10.1177/2158244014553585.

47 Milivojevic and Segrave.

48 Musto and boyd; Milivojevic and Segrave.

49 A Ahuja, 'Surveillance from the Skies May Help the Fight against Modern Slavery', Financial Times, 27 February 2019, https://www.ft.com/content/e16ea530-39b511e9-9988-28303f70fcff.

50 J Ham, M Segrave, and S Pickering, 'In the Eyes of the Beholder: Border enforcement, suspect travellers and trafficking victims', Anti-Trafficking Review, issue 2, 2013, pp. 51-66, https://doi.org/10.14197/atr.20121323. 
Point of Tension 1. E-trafficking and cyber-modern slavery are committed by organised criminals

As is the case with its terrestrial version, the discourse around e-trafficking is premised on an assumed link between organised crime and trafficking that needs to be combated via collaborative, multinational law enforcement mechanisms:

The internet offers the opportunity for trafficking to be an organized crime. There are trafficking rings where girls are moved from Brussels to Athens to London. They are advertised on sites and moved around Europe with the pimp organising the website. Sometimes the girls are so well controlled the pimp doesn't even need to travel with them in order to make them do what he wants. This makes it even more difficult to investigate as if the crime is taking place in various countries, who will investigate the case? ${ }^{51}$

In framing the 'trafficking-technology nexus' in this way, narrative setters shift the trafficking/slavery debate back to the hyper-simplified bad vs. good framework, in which evil perpetrators have to be punished, innocent victims 'rescued', while stakeholders such as nation-states and businesses that contribute to or sustain conditions in which exploitation occurs are absolved of any responsibility. What is more, the suggestion that businesses should employ technologies such as biometrics or facial recognition to address risks under new and emerging modern slavery legislation also distracts from standard business operating practices which contribute to exploitation.

Clamping down on the narrowly defined organised crime problem, as our research on terrestrial and e-trafficking demonstrates, often results in immobilising both offenders and potential victims. ${ }^{52}$ Technology, thus, assists in furthering the creation of binaries out of the trafficking/slavery complexity. ${ }^{53}$ By focusing on (however few or many) 'bad apples', loosely defined as organised criminals, structural causes of exploitation, limited mobility, and restricted labour rights are likely to remain ignored.

51 European Police Chief, cited in Cunningham, p. 12.

52 M Segrave and S Milivojevic, 'Human Trafficking: Examining global responses', in G Barak (ed), The Routledge International Handbook of the Crimes of the Powerful, Routledge, Abingdon and Oxon, 2015, pp. 132-143; Milivojevic and Segrave, 2017; Segrave, Milivojevic, and Pickering, 2018.

53 H Lewis and L Waite, 'Migrant Illegality, Slavery and Exploitative Work', in C Craig, A Balch, H Lewis, and L Waite (eds), The Modern Slavery Agenda: Policy, politics and practice in the UK, Polity Press, Bristol and Chicago, 2019, pp. 219-242. 
Point of Tension 2. E-trafficking and cyber-modern slavery mostly happen in sex industry

Concerns about technology initially emerged around the sites linked to the sex industry. These anxieties pertaining to new technologies were linked to antiprostitution, abolitionist and law enforcement agendas. ${ }^{54}$ Critically, as Musto and boyd argue, technology-mediated interventions further blur the boundaries between trafficking and sex work and subject those perceived to be at risk to surveillance and monitoring. ${ }^{55}$ We will return to this critical point in a moment.

Conflating trafficking and/or modern slavery with sex work contributes to the confusion around e-trafficking or cyber-slavery, as is evident in the following comments by European law enforcement officers:

Modern slavery victims are being duped and/or advertised online ... We were told of one website alone which offers over 6,500 women per day for sexual services, including approximately 500 in each of two London boroughs. This is cyber slavery. ${ }^{56}$

You need to focus on the fact that this is modern slavery and obviously when you see the online profile of these escort girls you can normally tell where something is wrong. You do need to tell citizens that if they are going to see a prostitute there will be a bad guy involved in this. You have to make people aware and they need a good disincentive. ${ }^{57}$

Thus, the burgeoning dominance of the concept of modern slavery is arguably bringing us back to the very beginning of counter-trafficking efforts, when, as we argue elsewhere, the blurred boundaries between sex work and trafficking and the focus on organised crime shaped the interventions, yet yielded modest results at best. ${ }^{58}$

54 M Thakor and d boyd, 'Networked Trafficking: Reflections on technology and the anti-trafficking movement', Dialectical Anthropology, issue 37, 2013, pp. 277-290, https://doi.org/10.1007/s10624-012-9286-6.

55 Musto and boyd, p. 464.

56 Cunningham, p. 33.

57 Ibid., p. 36.

58 Segrave and Milivojevic, 2015; Milivojevic and Segrave, 2017; Segrave, Milivojevic, and Pickering, 2018. 
Point of Tension 3. Trafficking/slavery perpetrators could be successfully identified/ located by technology

Suggestions that technology can play a vital role in identifying, counting, and countering trafficking/slavery are growing. ${ }^{59}$ We argue that such suggestions should be taken with caution, not only because of the limitations of technology but also because trafficking and modern slavery should not be framed solely as individual deviance, or organised crime. Focusing on individual perpetrators/transnational organised criminal networks and looking for them in the digital realm or with the help of technology in border crossings and fish farms is going to produce some results (as specific perpetrators and victims are likely to be uncovered). Yet, the issues pertinent to the social context in which such exploitative practices occur cannot be captured by retina scans or drones.

As such, the notion that surveillance of putative perpetrators and victims might somehow unpack the complexity of trafficking and slavery practices is unrealistic. We had earlier flagged the negative impact of surveillance on victims of trafficking, and how such surveillance easily translates into gendered border practices. ${ }^{60}$ Looking for suspicious content or calls for more regulatory mechanisms online are easy 'solutions' that do not tackle the root causes of the problem. ${ }^{61}$ More significantly, the danger that surveillance or other technological advancements might assist in furthering state control over human mobility and people's access to labour markets is genuine. The 'humanitarian' element of such interventions is often used to justify border-hardening practices, or the removal of non-citizens and workers in low-paid, low-skilled industries (agriculture, mining, fishing, and the like). Under the slogan of 'rescuing the slaves', such interventions mask the fact that they can be (and often are) used to regain control over mobility and ensure that only 'good' (authorised, 'regular') mobility is permitted. ${ }^{62}$ As Lyon notes, surveillance was and always will be used for social sorting, for the taxonomy of populations as a foundation for differential treatment. ${ }^{63}$ In countering

59 See, for example, Cunningham; B Jackson et al., 'Analysing Slavery Through Satellite Technology: How remote sensing could revolutionise data collection to help end modern slavery', Journal of Modern Slavery, vol. 4, no. 2, 2018, pp. 169-199.

60 Milivojevic and Segrave, 2017.

61 Thakor and boyd.

62 F Gerry, J Muraszkiewicz and N Vavoula, 'The Role of Technology in the Fight against Human Trafficking: Reflections on privacy and data protection concerns', Computer Law and Security Review, vol. 32, issue 2, 2016, pp. 205-217, https://doi.org/10.1016/j. clsr.2015.12.015.

63 D Lyon, 'Surveillance as Social Sorting: Computer codes and mobile bodies', in D Lyon (ed.), Surveillance as Social Sorting: Privacy, risk and digital discrimination, Routledge, London, 2003, pp. 13-30. 
trafficking and slavery, surveillance-based efforts are likely to result in strategies that actively prevent (mostly women) migrants from seeking opportunities abroad.

Point of Tension 4. Victims need to be rescued and perpetrators punished, with the help of technology

The 'rescue industry', ${ }^{64}$ it is often argued, should use technology to free the modern slaves. Claims that aerial surveillance (from satellites and drones) and other technological innovations can be used to 'spot' the victims and rescue them from slavery ${ }^{65}$ are a continuation of a discourse outlined above.

With the emergence of modern slavery legislation requiring large businesses to take action on slavery in their supply chains, corporate-developed and led tech solutions may be used as substitutes for more effective anti-slavery efforts, including freedom of association and collective bargaining. For example, various groups assert that modern slavery can be addressed through artificial intelligence, big data and tech-based risk assessment by identifying global risks and violations. ${ }^{66}$ However, identifying risks and violations is not a guarantee of remediation. A recent seven-country study by the British Academy found that whilst 'duediligence-oriented technology tools ... help[ed] control risk in supply-chain hot spots, [they] rarely identified modern slavery due to gaining little trust from workers, and business clients not being ready to expose or address modern slavery'. ${ }^{67}$ Conversely, empowerment-oriented worker feedback tools were found to regularly identify modern slavery, forced labour, and human trafficking and to assist exploited workers. Despite their demonstrated effectiveness, the researchers found that most of these tools had no connection to a business's due diligence.

It is time to remind ourselves that researchers for some time now have been documenting how purportedly humanitarian interventions often backfire and create more harm rather than fight trafficking. Works of Rutvica Andrijasevic, Claudia Aradau, Karina Horsti, Céline Nieuwenhuys, Antoine Pécoud, Gretchen Soderlund and many others should be the starting point in questioning

64 L M Agustin, Sex at the Margins: Migration, labour markets and the rescue industry, Zed Books, London, 2006.

65 Jackson et al.

66 G Markovitz, 'How AI and Satellite Imaging Can Stamp Out Modern Slavery', World Economic Forum, 22 January 2020, https://www.weforum.org/agenda/2020/01/howai-and-satellite-imaging-tech-can-put-an-end-to-modern-slavery.

${ }^{67}$ L Rende Taylor and E Shih, 'Worker Feedback Technologies and Combatting Modern Slavery in Global Supply Chains: Examining the effectiveness of remediation-oriented and due-diligence-oriented technologies in identifying and addressing forced labour and human trafficking', Journal of the British Academy, vol. 7, no. 1, 2019, pp. 131-165, p. 131, https://doi.org/10.5871/jba/007s1.131. 
humanitarian interventions supplemented by technology. While technology can certainly be an essential factor in addressing trafficking and slavery, its use to 'locate and rescue' victims, and 'locate and bring to justice' perpetrators obfuscates the complex and non-linear nature of these exploitative practices.

\section{Conclusion: Moving towards a different paradigm}

In this paper, we do not advocate that researchers, activists, NGOs, and government agencies abstain from investigating the role of technology within the context of trafficking/slavery and exploitation more broadly. Quite the opposite: as researchers and social scientists concerned with technology's role in contemporary society, we ought to engage in the conversation about how the power of technological advancements can be harnessed in better understanding and addressing conditions in which exploitative practices occur and thrive. But before that we need to recalibrate some key premises in the conversation.

Firstly, we need to acknowledge that the Internet 'doesn't steal our humanity; it reflects it. The Internet doesn't get inside us; it shows what's inside us. ${ }^{36}$ Technology is not a ruse, nor a saviour; this starting point is critical if we wish to avoid traps of technological determinism. Technology does not have the capacity (yet) to determine the development of our social structure and our values. It does not have the power to shift the paradigm, for better or for worse. However, the Internet, social media, and digital frontier technologies such as artificial intelligence and blockchain do reflect our views and values, and their impact on our lives is palpable.

Secondly, technology as a solution must be held up to scrutiny as should conceptions of slavery facilitated by technology. As it stands, the preoccupation of a range of actors (government agencies, businesses, NGOs) with 'ending' trafficking/slavery is a distraction. Not least because after almost two decades of this work, there is no indication that counter-trafficking efforts have had any demonstrable impact on reducing this form of exploitation. In place of accountability, we see again the shifting gaze and focus to lay accountability with individuals/consumers, businesses, and the like. Our gaze and attention are consistently away from the complexities of contemporary exploitative practices, policies that restrict migration and mobility opportunities, and regulations and policies that only on paper enable fundamental labour rights and legal migration opportunities for non-citizens. We, as individuals, are thus told to fix the problem: we should pay attention to what we buy, we should donate to counter-trafficking/

68 Josh Rose, the digital creative director of ad agency Deutsch LA, cited in Z Bauman and D Lyon, Liquid Surveillance, Polity Press, Cambridge and Malden, 2013, p. 25. 
slavery agencies to 'offset our slavery footprint', and ultimately report suspicious practices and potential victims/offenders through a mobile app. Similarly, businesses should invest in developing technology that will provide them with the equivalent of a 'slavery-free' stamp they can safely imprint on their products, even if those efforts have had little or no impact on the problem.

A robust evidence base is critical here, as is evidence within the local context. We should not build a grand theory of e-trafficking or cyber-slavery that is applicable to all contexts and all forms of exploitation. We suggest this notwithstanding the fact that evidence-based initiatives occasionally do little to reveal, if not obscure, the complex realities of trafficking experiences. ${ }^{69}$ Thus, we should start from the local context, and connect with practitioners, IT experts, activists, unions, workers' representatives, and victims to start building the research profile that can help us better understand what is going on, and what we can do about it. Why not, for example, invest in technological innovation that will empower migrant workers and enable them to share, map, and document exploitation, while also navigating a complex maze of the criminal justice, labour, and immigration systems? This is an argument for the disruption of the rescue mentality that has dominated the agenda thus far, towards bringing workers to the fore and asking them what they need and how we can help them. The key question we should be asking is what technology has to offer when it comes to sharing information, creating safety, and building strategy and effective remedies for exploitation. We should use technology to further contextualise the issue, rather than to streamline it. There will be no simple solutions to this problem, and we should give up on that idea before we waste too much energy and resources on potentially exciting and saleable but futile recommendations.

Thirdly, we need to understand how the language of modern slavery shapes our ideas, and consequently, our solutions to disrupt and prevent slavery and exploitation. As we have discussed, the anti-slavery movement and its predecessor, the anti-trafficking movement, have cast workers as victims, which has fundamentally shaped global responses as top-down, rather than worker-informed and worker-led. What is needed is an inversion of this so that solutions are built on what has been demonstrated to work rather than on what gives the appearance of what works. Technological innovations should not be framed as neoliberal instruments that can once and forever rid us from trafficking, poverty, exploitation, or inequality. To do this, we suggest that the disproportionate focus on large scale or corporate-led technological solutions to 'rescue victims' should be re-balanced with greater attention to building on existing work for understanding how workers

69 L Beutin, "How "Evidence-Based" Anti-Trafficking Campaigns Make Facts and Mismeasure Freedom', Open Democracy, 20 June 2019, retrieved 14 October 2019, https://www.opendemocracy.net/en/beyond-trafficking-and-slavery/rotten-core-ofevidence-based-anti-trafficking-campaigns. 
are using technology to navigate migration pathways to find decent work. ${ }^{70}$

We also recommend caution when theorising that a crisis effectively generated by neoliberal capitalism can somehow help the further development of the same neoliberal capitalism. There is some danger in theorising that the moral issue of solving the slavery crisis has a clear monetary value attached: that the freed slaves will eventually become consumers. Liberation, as Kevin Bales suggests, leads to economic growth and can ultimately assist in transforming developing nations into successful neoliberal capitalist societies. ${ }^{71}$ Yet, where in this analysis is the recognition of the impact of limitations on mobility, restricted access to labour markets in countries of origin and destination, and the vested interest of global capitalism in low-skilled, low-paid labour in creating conditions for trafficking/ slavery-like exploitation? So too, where is the recognition that those who experience exploitation use technology to monitor opportunities, to share knowledge, to leave exploitative contexts and seek other less-exploitative opportunities elsewhere? In many cases, they are seeking opportunities to keep working, to survive, to thrive and to ensure their families in countries of origin can be supported. ${ }^{72}$ Where is the technological innovation to support and enable this?

We agree with O'Connell Davidson and many others in their claim that technology, as it is framed in contemporary anti-trafficking/slavery discourse, represents an extension of neocolonial and interventionist approaches to trafficking. In it, the rescuers-a range of mostly white, privileged countertrafficking actors—aim to: 1) save those in danger: racially and ethnically different 'Others' from the Global South, either in their countries of origin or when they are 'imported' to western liberal democracies, and 2) punish the evil traffickers/ slaveholders, who are also the 'Other': organised criminal groups from developing nations. Individual freedom, thus, is something that can be stolen but also regifted $^{73}$ and is ultimately isolated and disconnected from social forces of neoliberal capitalism, racism, and political, economic and labour rights. In so doing, we ultimately objectify and remove any agency from those we consider enslaved. The primary beneficiary of such an approach to the trafficking/slavery-technology conundrum is the security state, but also agencies and actors absolved of

70 M Segrave, Exploited and Illegal: Unlawful migrant workers in Australia, Monash University, Melbourne, 2017; B Farbenblum, L Berg, and A Kintominas, Transformative Technology for Migrant Workers: Opportunities, challenges, and risks, Open Society Foundations, New York, 2018, https://www.opensocietyfoundations.org/sites/default/ files/transformative-technology-formigrant-workers-20181107.pdf; Rende Taylor and Shih, 2019.

71 Paraphrased in O'Connell Davidson, 2015.

72 M Segrave, 'Theorizing Sites and Strategies of Differential Inclusion: Unlawful migrant workers in Australia', Theoretical Criminology, vol. 23, no. 2, 2019, pp. 194-210, https://doi.org/10.1177/1362480619827527.

73 Ibid. 
accountability for lack of results when it comes to countering trafficking/slavery.

The different paradigm we advocate needs to assess the risks and vulnerabilities for migrants linked to national/regional labour and migration frameworks. Technology has a lot to offer in this context. It should be harnessed to give us a better understanding of how people find themselves in exploitative situations, but also to return agency and leverage to workers who may be vulnerable to trafficking. But first, we need to explore how technology can help us in understanding the complexities of contemporary exploitative practices. Evidence is critical here. After this, we need to ask how do we know that counter-trafficking/ slavery interventions are having an impact. In doing so, we should rely on rigorous research and evidence, and avoid the path we have witnessed in some 20 years of engagement with 'terrestrial' trafficking. Finally, we must not accept technology as a replacement for strategies that empower workers to improve their own labour conditions rather than wait passively to be rescued.

Dr Sanja Milivojevic is a Research Fellow in Criminology at La Trobe University, Melbourne, and Associate Director of Border Criminologies at Oxford University. Sanja holds LLB and LLM from Belgrade University's Law School, and PhD from Monash University, Australia. She has been a visiting scholar at the University of Oxford, University of Oslo, Belgrade University, and University of Zagreb, as well as a Public Interest Law Fellow at Columbia University's Law School in New York. Sanja publishes in English and Serbian. She is the author of Border Policing and Security Technologies (Routledge, 2019). Email: s.milivojevic@latrobe.edu.au

Heather Moore is a Consultant with the Trafficking and Slavery Research Group, Monash University, Australia. She has nearly 17 years of experience in the areas of programme management, capacity building, policy, and research. She provides expert witness services in trafficking matters and is a consultant with a focus on organisational capacity building to effectively identify, remediate, and evaluate responses to human trafficking. She has published works on effective stakeholder collaboration in counter-trafficking operations, the Australian response to contemporary forms of slavery, and trafficking for domestic servitude in Australia. Email: heather.moore@monash.edu

Marie Segrave is an Associate Professor in Criminology at Monash University, Australia. She leads the Trafficking and Labour Exploitation research agenda via the Monash Migration and Inclusion Centre, which is also home to the Border Crossing Observatory. She has undertaken extensive research on trafficking and slavery-like practices, the design and implementation of counter-trafficking efforts and the role and impact of migration regulation and border control on exploitative practices. Marie also publishes and undertakes research as a member of the Monash Gender and Family Violence team with a focus on migration regulation and family and domestic violence. Email: marie.segrave@monash.edu 